\title{
AKTIVITAS PROTEOLITIK PAPAIN KASAR GETAH BUAH PEPAYA DENGAN BERBAGAI METODE PENGERINGAN
}

\author{
Deivy Andhika Permata, Hafizul Ikhwan, dan Aisman \\ Program Studi Teknologi Hasil Pertanian, Fakultas Teknologi Pertanian, Universitas Andalas \\ Email: deivyandhika@yahoo.co.id
}

\begin{abstract}
ABSTRAK
Papain merupakan enzim golongan protease yang banyak digunakan di industri. Salah satu proses penting dalam menghasilkan produk papain kasar adalah pengeringan. Penelitian ini bertujuan untuk mengetahui kadar air, kadar abu, kadar protein, dan aktivitas proteolitik papain kasar getah buah pepaya dengan berbagai metode pegeringan. Metode pengeringan yang digunakan pada penelitian ini, yaitu pengeringan matahari (solar drying), pengeringan kabinet (cabinet drying), pengeringan vakum (vacuum drying) dan pengeringan beku (freeze drying). Berdasarkan hasil penelitian yang dilakukan disimpulkan bahwa metode vakum menghasilkan aktivitas proteolitik tertinggi dibanding metode lainnya.

Kata kunci: papain, pengeringan, proteolitik
\end{abstract}

\section{PENDAHULUAN}

Enzim merupakan biokatalisator yang diproduksi oleh sel dan telah banyak dimanfaatkan dalam bidang industri. Sebagai biokatalisator, enzim dapat mempercepat suatu reaksi tanpa ikut bereaksi. Pada industri yang menggunakan enzim, 59\% enzim yang digunakan adalah protease, salah satunya adalah papain (Soda dan Agustini, 2013).

Kemampuan papain untuk memecah molekul protein, membuatnya menjadi produk yang sangat bermanfaat bagi kehidupan manusia baik di rumah tangga maupun industri, seperti pada proses pengempukan daging, pembuatan konsentrat protein, pembuatan dadih, pelembut kulit pada industri penyamak kulit, penjernih pada industri bir, serta bahan obat dan kosmetik. Papain dapat kita peroleh dari getah pepaya, baik dalam buah, batang, dan daunnya. Menurut Indriani, Affandi, Sunarwati (2008) batang, daun dan buah pepaya muda mengandung getah berwarna putih. Di dalam getah pepaya terdapat lebih dari 50 asam amino antara lain asam aspartat, treonin, serin, asam glutamat, prolin, glisin, alanin, valine, isoleusin, leusin, tirosin, fenilalanin, histidin, lysin, arginin, tritophan, dan sistein. Selain itu getah juga mengandung suatu enzim pemecah protein atau enzim proteolitik yang disebut papain.

Salah satu proses penting dalam menghasilkan produk papain kasar adalah pengeringan. Buckle, Edwards, Fleet dan Wooter (1985), mengemukakan bahwa setiap metode pengeringan memiliki faktorfaktor yang akan mempengaruhi kecepatan pengeringan dan kualitas produk kering yang dihasilkan diantaranya suhu, tekanan, kelembaban udara, kecepatan aliran udara dan lamanya waktu pengeringan yang digunakan. Karakteristik papain yang stabil terhadap faktor suhu dan waktu pengeringan menjadi pertimbangan pada pemilihan alat dan metode pengeringan untuk menghasilkan produk papain kasar. Metode pengeringan yang digunakan pada penelitian ini, yaitu pengeringan matahari (solar drying), pengeringan kabinet (cabinet drying), pengeringan vakum (vacuum drying) dan pengeringan beku (freeze drying).

Penelitian ini bertujuan untuk mengetahui kadar air, kadar abu, kadar protein, dan aktivitas proteolitik papain kasar dengan berbagai metode pengeringan yang berbeda.

\section{METODOLOGI PENELITIAN}

\section{A. Bahan dan Alat}

Bahan yang digunakan pada penelitian ini, yaitu getah hasil sadapan buah pepaya Penang (Carica papaya, L.), $\mathrm{Na}_{2} \mathrm{~S}_{2} \mathrm{O}_{5} 0,7 \%$, alkohol $92 \%$, kasein $1 \%$, asam trikloroasetat (TCA) $30 \%$ (b/v), tirosin (0$90 \mu \mathrm{g} / \mathrm{ml}$ ), buffer fosfat $0,1 \mathrm{M} \mathrm{pH} \mathrm{7,} \mathrm{pereaksi} \mathrm{biuret,} \mathrm{bovine} \mathrm{serum} \mathrm{albumin} \mathrm{(BSA)} 22 \%$ dan aquades. Alat yang digunakan dalam penelitian ini adalah oven vakum (Memmert Vacuubrand MZ 2C NT), cabinet dryer (Corsair), freeze dryer (Edwards Modulyo BS2208), digital pocket weatherman (Mannix SAM700BAR), environment meter (Krisbow KW06-291), tanur, plat kaca, erlenmeyer, 
spektrofotometer UV-1800, neraca analitik, $\mathrm{pH}$ meter, centrifuge, water bath, moisture analyzer, dan vortex.

\section{B. Metode Penelitian}

Penelitian ini merupakan penelitian eksploratif dengan menggunakan metode pengeringan yang berbeda, yaitu metode pengeringan matahari (solar drying), pengeringan kabinet (cabinet drying), pengeringan vakum (vacuum drying) dan pengeringan beku (freeze drying). Setiap pengeringan dilakukan sebanyak tiga kali ulangan.

\section{Pelaksanaan Penelitian}

\section{Persiapan Bahan Baku (Cahyono, 2013)}

Bahan baku yang digunakan adalah getah pepaya yang disadap dari buah berumur 2,5-3 bulan, penyadapan dilakukan pada sore hari dengan kedalaman 1,5 mm dari kulit buah.

\section{Pembuatan Papain Kasar}

a. Pengendapan Protein Getah Pepaya (Warisno, 2003)

Getah pepaya hasil penyadapan dicampur dengan aktivator natrium metabisulfit $0,7 \%$ dengan perbandingan 1:4. Campuran tersebut diaduk dengan menggunakan magnetic stirrer dengan kecepatan 600 rpm hingga terbentuk campuran bewarna putih yang kemudian ditambahkan dengan alkohol 92\% sebanyak 5 kali volume getah pepaya. Kemudian campuran disimpan di dalam lemari pendingin pada suhu $4-8^{\circ} \mathrm{C}$ selama $12 \mathrm{jam}$. Setelah terbentuk endapan putih dibagian dasar campuran, cairan dipisahkan dan endapan digunakan untuk proses selanjutnya.

\section{b. Pengeringan Papain Kasar}

a) Pengeringan Matahari (Solar Drying) (Cahyono, 2013)

Endapan disebar merata ke dalam wadah plat kaca. Setelah itu dijemur dibawah sinar matahari di dalam ruang solar dryer selama 8 jam. Getah dikeringkan hingga terbentuk serpihan-serpihan bewarna putih kecoklatan.

b) Pengeringan Kabinet (Cabinet Drying) (Cahyono, 2013)

Endapan disebar merata ke dalam wadah plat kaca. Wadah tersebut dimasukkan ke dalam lemari pengering (cabinet dryer) dengan suhu $55^{\circ} \mathrm{C}$ selama 6 jam. Getah dikeringkan hingga terbentuk serpihan-serpihan bewarna putih kecoklatan.

c) Pengeringan Vakum (Vacuum Drying) (Harlim, 2010)

Endapan disebar merata ke dalam wadah plat kaca. Wadah tersebut dimasukkan ke dalam oven vakum dengan suhu $45^{\circ} \mathrm{C}$ selama 8 jam. Tekanan yang digunakan pada pengeringan vakum adalah 150 mb. Getah dikeringkan hingga terbentuk serpihan-serpihan bewarna putih kecoklatan. Serpihan kering dihaluskan hingga berbentuk bubuk dan selanjutnya dikemas dengan baik.

d) Pengeringan Beku (Freeze Drying) (Silaban, 1994)

Endapan dimasukkan ke dalam erlenmeyer $250 \mathrm{ml}$ dan dikeringkan dengan menggunakan freeze dryer pada suhu $-33^{\circ} \mathrm{C}$ dengan tekanan $0,1 \mathrm{mb}$ selama $4,5 \mathrm{jam}$. Getah dikeringkan hingga terbentuk serpihan-serpihan bewarna putih kecoklatan. Serpihan kering dihaluskan hingga berbentuk bubuk dan selanjutnya dikemas dengan baik.

\section{Prosedur Analisis}

Analisis yang dilakukan pada produk papain kasar yang dihasilkan dengan metode pengeringan adalah kadar air, kadar abu, kadar protein metode Biuret (Andarwulan et al., 2011) dan aktivitas proteolitik metode Murachi (Sebayang, 2006).

\section{HASIL DAN PEMBAHASAN}

\section{A. Identifikasi Metode Pengeringan dan Kadar Air Papain Kasar}

Setiap metode pengeringan yang digunakan memiliki karakteristik pengeringan yang berbeda seperti pada Tabel 1. Karakteristik pengeringan yang mempengaruhi kecepatan pengeringan disebut kualitas udara. Menurut Hasibuan (2004), kualitas udara meliputi suhu, kelembaban udara, tekanan udara dan kecepatan aliran udara. Semua proses pengeringan papain dilakukan sampai kadar air $\pm 9 \%$. 
Berdasarkan hasil penelitian diperoleh kadar air papain kasar seperti pada Gambar 1. Kadar air yang terkandung dalam produk papain kasar yang dihasilkan masih dibawah nilai kadar air yang ditentukan dalam spesifikasi papain kasar menurut Botanical Derivatives Catalogue of Dr. Madis Laboratories, Inc yaitu maksimal $18 \%$.

Tabel 1. Kualitas Udara Pada Berbagai Alat yang Digunakan

\begin{tabular}{|l|c|c|c|c|}
\hline Metode Pengeringan & Suhu $\left({ }^{\circ} \mathrm{C}\right)$ & $\begin{array}{c}\text { Kelembaban } \\
\text { Udara }(\%)\end{array}$ & $\begin{array}{c}\text { Tekanan } \\
\text { Udara }(\mathrm{mb})\end{array}$ & Waktu (Jam) \\
\hline Solar Drying & $29-43$ & $83-44$ & 981 & 8 \\
\hline Cabinet Drying & 55 & $85-48$ & 980 & 6 \\
\hline Vacuum Drying & 45 & $96-50$ & 150 & 8 \\
\hline Freeze Drying & -33 & - & 0,1 & 4,5 \\
\hline
\end{tabular}

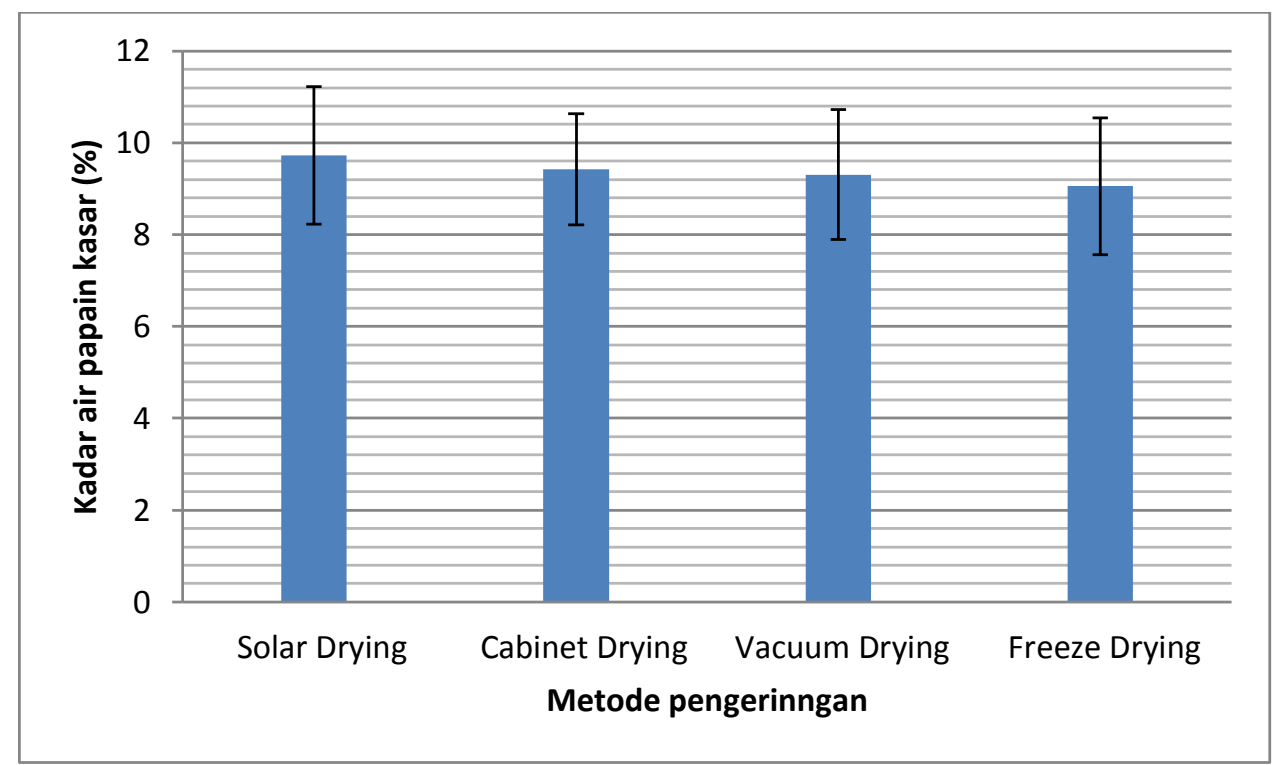

Gambar 1. Kadar Air Papain Kasar dengan Berbagai Metode Pengeringan

Mekanisme pengeringan dari alat yang digunakan terdiri atas dua, yaitu pengeringan yang menggunakan panas (Solar Drying, Cabinet Drying, dan Vacuum Drying), dan pengeringan beku (Freeze Drying). Berdasarkan Tabel 1 dapat dilihat pada pengeringan yang menggunakan panas, pengeringan kabinet (Cabinet Drying) memiliki suhu yang lebih tinggi. Semakin tinggi suhu pengeringan akan mempercepat proses penguapan air yang terkandung dalam bahan (Muchtadi dan Sugiyono, 2013), hal ini terlihat dari waktu yang dibutuhkan untuk mengahasilkan papain kasar dengan kadar air yang hampir sama (Gambar 1) lebih pendek dibandingan dengan metode lainnya. Disamping itu menurut Muchtadi dan Sugiyono (2013) tekanan udara yang rendah menyebabkan suhu yang dibutuhkan untuk menguapkan air menjadi lebih rendah. Tekanan udara yang digunakan pada pengeringan matahari dan pengeringan kabinet merupakan tekanan lingkungan tanpa dimodifikasi, sedangkan tekanan udara pada pengeringan vakum dan pengeringan beku dimodifikasi dengan menggunakan pompa vakum. Berikut papain kasar yang dihasilkan dengan berbagai metode pengeringan (Gambar 2). 


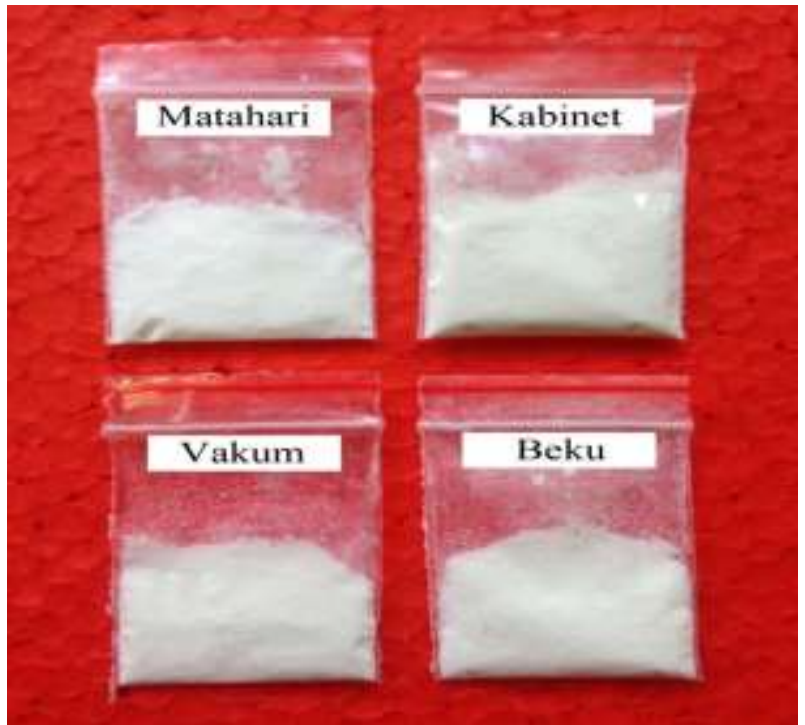

Gambar 2. Papain Kasar dengan Berbagai Metode Pengeringan

\section{B. Kadar Abu Papain Kasar}

Berdasarkan hasil penelitian diperoleh kadar abu papain kasar dari berbagai metode pengeringan berkisar antara 12,81-13,78\%, seperti pada Gambar 3 berikut ini. Kadar abu yang terkandung dalam produk papain kasar yang dihasilkan masih di bawah nilai kadar abu menurut Botanical Derivatives Catalogue of Dr. Madis Laboratories, Inc yaitu sebesar 14\%. Menurut Prastari (2015) getah buah pepaya segar memiliki kadar abu $11,35 \%$. Tingginya kadar abu yang diperoleh dari papain kasar disebabkan karena dalam proses pembuatan papain kasar ditambahkan aktivator natrium metabisulfit $\left(\mathrm{Na}_{2} \mathrm{~S}_{2} \mathrm{O}_{5}\right)$. Menurut Nastiti (2014), Natrium metabisulfit mengandung mineral seperti $\mathrm{Na}$ dan $\mathrm{S}$ sehingga meningkatkan kadar abu dari papain kasar yang dihasilkan.

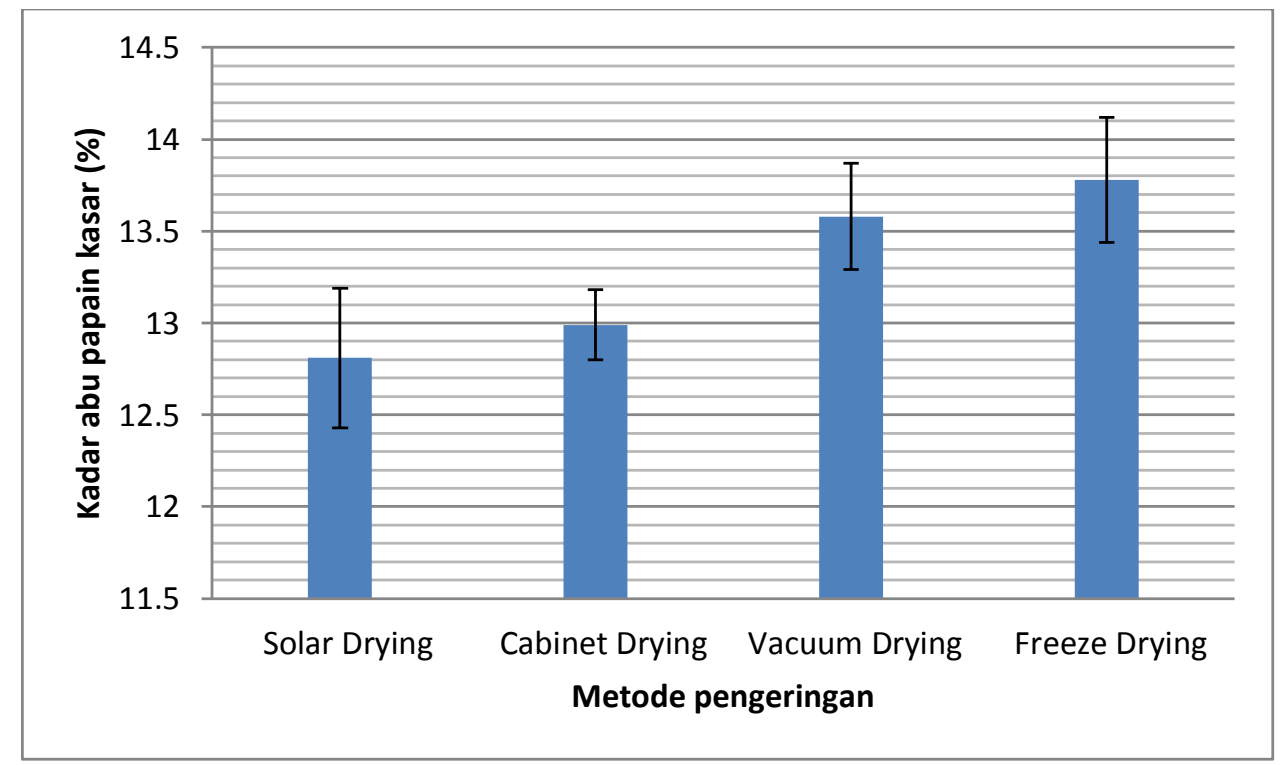

Gambar 3. Kadar Abu Papain Kasar dengan Berbagai Metode Pengeringan

\section{Kadar Protein dan Aktivitas Proteolitik Papan Kasar}

Kadar protein dan aktivitas proteolitik papain kasar dapat dilihat pada Gambar 4 dan Gambar 3 berikut ini: 


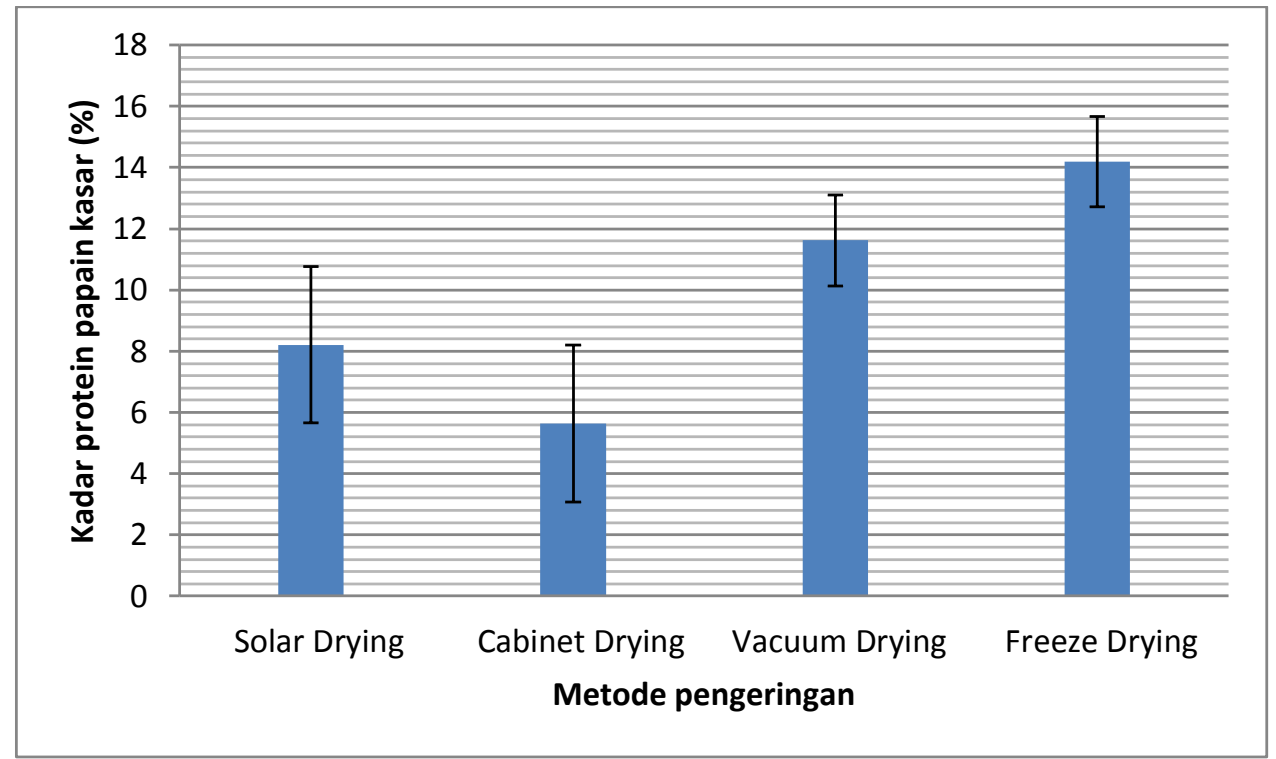

Gambar 4. Kadar Protein Papain Kasar dengan Berbagai Metode Pengeringan

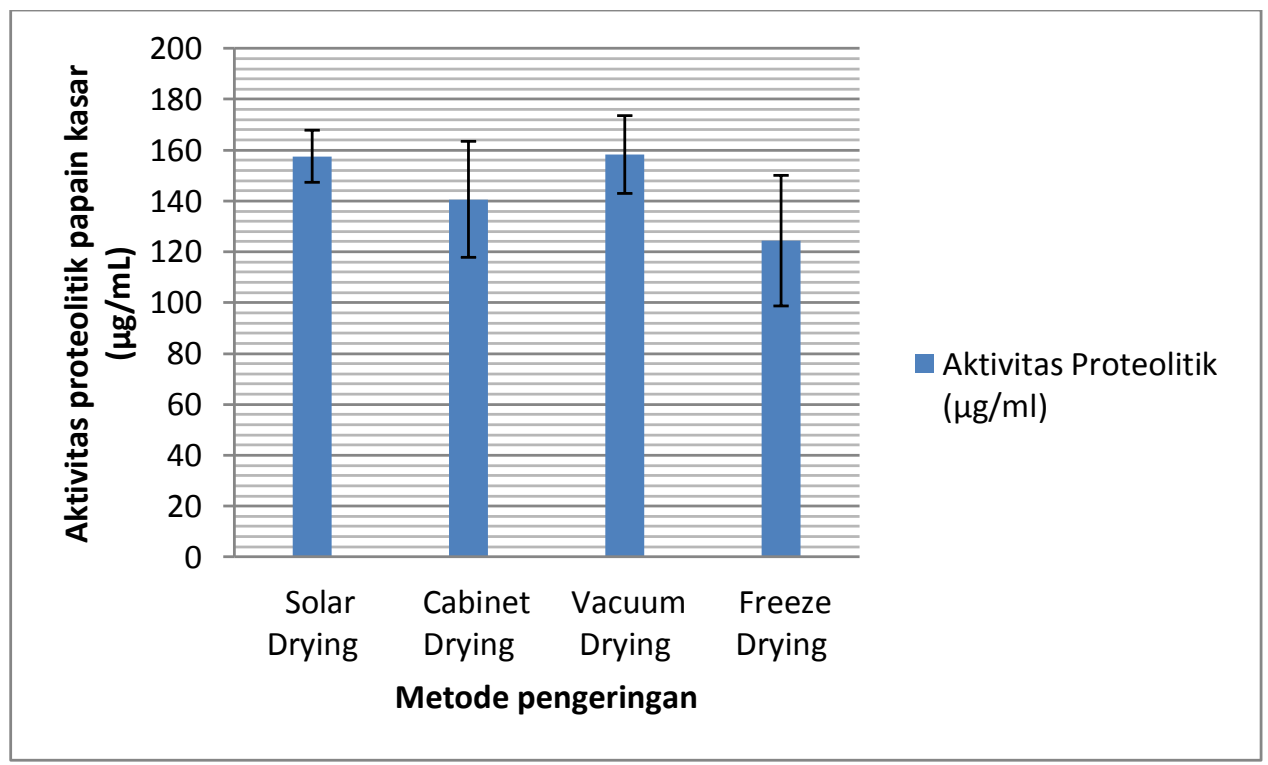

Gambar 5. Aktivitas Proteolitik Papain Kasar dengan Berbagai Metode Pengeringan

Berdasarkan hasil penelitian diperoleh kadar protein papain kasar yang tertinggi adalah dengan metode pengeringan beku sebesar $14,19 \%$. Hal ini disebabkan mekanisme pengeringan beku tidak menggunakan pemanasan, sehingga kandungan protein yang terkandung dapat dipertahankan (Muchtadi dan Sugiyono, 2013). Kadar Protein terendah dihasilkan oleh papain kasar dengan metode pengeringan cabinet sebesar 5,64\%. Menurut Desrosier (1969), suhu tinggi yang digunakan pada proses pengeringan menyebabkan kerusakan pada protein. Suhu tinggi yang digunakan pada metode pengeringan cabinet $\left(55^{\circ} \mathrm{C}\right)$ menyebabkan kerusakan pada protein yang terkandung pada papain kasar sehingga menurunkan kadar protein papain kasar.

Kandungan protein yang tinggi belum tentu menunjukkan aktivitas proteolitik yang tinggi, karena tidak semua protein memiliki sisi aktif yang menjadikan protein tersebut sebagai enzim. Kualitas produk papain kasar tergantung pada aktivitas proteolitiknya. Semakin tinggi aktivitas proteolitik yang dihasilkan oleh papain kasar, maka akan semakin baik juga kualitas papain kasar tersebut. Metode pengeringan vakum menghasilkan produk papain kasar dengan aktivitas proteolitik tertinggi. Pada sistem vakum udara dan uap air yang terbentuk selama proses pengeringan dihisap. Menurut 
Purwowigati (1991) proses ini menghambat adanya oksigen yang dapat menurunkan aktivitas proteolitik enzim akibat proses oksidasi, sehingga aktivitas proteolitik papain kasar dapat dipertahankan. Papain kasar yang dihasilkan dengan metode pengeringan matahari juga menghasilkan aktivitas proteolitik yang cukup tinggi dibandingkan dengan metode pengeringan kabinet yang memiliki tekanan udara yang tidak jauh berbeda (Tabel 1). Hal ini disebabkan suhu pada pengeringan kabinet yang tinggi $\left(55^{\circ} \mathrm{C}\right)$ mengakibatkan penurunan aktivitas proteolitik papain kasar yang dihasilkan. Suhu tinggi pada pengeringan kabinet menyebabkan tingginya reaksi oksidasi yang terjadi. Proses oksidasi menyebabkan sisi aktif papain kasar menjadi inaktif sehingga menurunkan aktivitas proteolitiknya (Ksumastyaningrum, 2002).

Proses pembekuan dapat menurunkan aktivitas proteolitik sehingga nilai aktivitas proteolitik papain kasar yang dihasilkan dengan menggunakan metode pengeringan beku menjadi lebih rendah dibandingkan dengan papain kasar yang dihasilkan dengan metode pengeringan menggunakan panas. Pada proses pembekuan, terjadi perubahan konformasi yang menyebabkan sisi aktif enzim tidak dapat berikatan dengan substrat. Perubahan ini bersifat irreversible atau tidak dapat balik, sehingga terjadi penurunan aktivitas proteolitik setelah proses sublimasi (Schwimmer, 1981 dalam Purwowigati, 1991). Menurut Muchtadi dan Sugiyono (2013), proses pembekuan mengakibatkan ikatan sulfhidril (-SH) pada sisi aktif enzim berubah menjadi ikatan disulfida (-S-S-). Perubahan sisi aktif tersebut menyebabkan enzim kehilangan aktivitas proteolitiknya, sehingga metode pengeringan beku menghasilkan papain kasar dengan aktivitas proteolitik paling rendah (Muchtadi dan Sugiyono, 2013).

\section{KESIMPULAN}

Berdasarkan hasil penelitian yang dilakukan disimpulkan bahwa metode pengeringan vakum menghasilkan aktivitas proteolitik tertimggi dibanding metode lainnya.

\section{DAFTAR PUSTAKA}

Andarwulan, U., Kusnandar, F. dan Herawati, D. 2011. Analisis Pangan. Dian Rakyat. Jakarta.

Buckle, K.A., Edwards, R.A. Fleet, G.H. dan Wooter, M. 1985. Food Science. Purnomo, H dan Adiono. (penerjemah). 2010. Ilmu Pangan. UI-Press. Jakarta.

Cahyono, B. 2013. Kiat Sukses Bisnis Getah Pepaya. Pustaka Mina. Jakarta.

Desrosier, N.W. 1969. The Technology of Food Preservation. Muljohardjo, M. (penerjemah). 1988. Teknologi Pengawetan Pangan. UI-Press. Jakarta.

Harlim, M.S. 2010. Studi Penentuan Aktivitas Crude Enzim Papain dalam Mikrokapsul Ca Alginat Kitosa. [Skripsi]. Jurusan Kimia FMIPA. USU: Medan.

Hasibuan, R. 2004. Mekanisme Pengeringan. http://www.repository.usu.ac.id [13 Juni 2016].

Indriani, N.L.P., Affandi, Sunarwati, D. 2008. Penggelolaan Kebun Pepaya Sehat. Balai Penelitian Tanaman Buah Tropika. Pusat Penelitian dan Pengembangan Holtikultura. Badan Penelitian dan Pengambangan Pertanian. ISBN: 978-979-1465-03-8.

Ksumastyaningrum, D. 2002. Pengaruh Penambahan Antioksidan dan Aktivator untuk Mempertahankan Aktivitas Proteolitik Getah Pepaya Selama Penyimpanan. [Skripsi]. Fakultas Teknologi Pertanian IPB: Bogor.

Muchtadi, T.R dan Sugiyono. 2013. Prinsip Proses dan Teknologi Pangan. Alfabeta. Bandung.

Nastiti, M.A., Hendrawan, Y., Yulianingsih, R. 2014. Pengaruh Konsentrasi Natrium Metabisulfit dan Suhu Pengeringan terhadap Karateristik Tepung Ampas Tahu. Jurnal Biopres Komoditas Tropis 2 (2): 100-106.

Prastari, C., Desmelati dan Karnila, R. 2015. Penggunaan Tepung Getah Pepaya Konsentrasi Berbeda terhadap Karakteristik Mutu Kecap Ikan Gabus (Channa Striata). Jurnal Online Mahasiswa Perikanan dan Ilmu Kelautan 2 (2): 1-9.

Purwowigati, M.I. 1991. Kajian Aspek Tekno-Ekonomi Proses Pengeringan dalam Produksi Papain Kasar. [Skripsi]. Fakultas Teknologi Pertanian IPB: Bogor.

Sebayang, F. 2006. Imobilisasi Enzim Papain dari Getah Pepaya dengan Alginat. Jurnal Komunikasi Penelitian 18 (2): 34-38 
Silaban, R. 1994. Studi Pemanfaatan Enzim Papain Getah Buah Pepaya untuk Melunakkan Daging. [Skripsi]. Jurusan Kimia FMIPA. UNIMED: Medan.

Soda, N.F., dan Agustini, R. 2013. Pengaruh Penambahan Ion $\mathrm{K}^{+}$Terhadap Aktivitas Enzim Papain. Surabaya. Jurusan Kimia. Universitas Negeri Surabaya. UNESA Journal of Chemistry Vol. 2, May 2013.

Warisno. 2003. Budi Daya Pepaya. Kanisius. Yogyakarta. 